\title{
The role of strategic agility in the IT sector
}

\author{
Miruna Florina LUNGU \\ Bucharest University of Economic Studies, Bucharest, Romania \\ Lungu.Miruna@gmail.com
}

\begin{abstract}
As we are living in a world governed by technology, the society becomes step by step more digitalized. The IT sector is now rooted both in our personal and professional lives, removing physical boundaries. Given these facts, the aim of this paper is to present an analysis of how strategic agility works hand in hand within the IT industry. Strategic agility represents a trigger for growth in this industry, contributing to its expansion and strategic business direction as part of the business environment. Thus, the objectives of the current paper are three-folded, namely: (1) what does strategic agility stands for in the IT industry; (2) how strategic agility is achieved within IT sector (3) which business areas of IT companies are impacted by strategic agility. In the journey of covering all these points, we will use mixed research methodology. The qualitative research contributes to a deeper understanding of the role strategic agility plays in the IT business. This section of the paper screens the targeted concepts of the research, acknowledging the challenges and opportunities triggered by strategic agility. The quantitative research method represented by a survey highlights through primary collected data a real case analysis of the IT industry. Various stakeholders operating in this industry bring their input to the development of this scientific paper, their opinion being sketched with the support of structured set of opened and closed questions. The findings of this research are collected and analyzed to mirror the significance of strategic agility as part of the IT industry. The paper aims to cover all the listed objectives, raising awareness of how technology is a vital strategic pillar of the business environment. Such results enhance our capacity of future value creation, enabling new opportunities for growth and innovation.
\end{abstract}

Keywords: strategic agility, IT, performance, strategy, change.

\section{Introduction}

A key point for strategic agility is sustainability. Paunescu (2009) highlights that an organization should monitor its results in relationship with its processes. Thus, Stachowiak et.al (2013) believe that strategic agility is for IT companies a bridge to optimize resources and business capability. The sustainability characteristic of strategic agility is supported by Jajja et.al (2018) as well. The authors point out that strategic agility represents a commitment to increased efficiency, shortened lead times and production. Paunescu et. al (2018) consider sustainability has four layers: knowledge, change, innovation, and ethics. These are embedded in strategic agility as well.

The paper's target is to point out how strategic agility represents a tool for enhancing performance for the IT companies. As the IT sector has started to bloom in the recent years, it becomes more and more active as the needs of the modern society aim to be digitalized. Chae et.al (2018) consider the main purpose of the IT sector is to convert traditional business model into digital business models. IT influences the products and services of a large portfolio of businesses accelerating the path to increased company performance. $\mathrm{Xu}$ and Koivumaki (2018) mention that the concept of strategic agility became more and more popular since its introduction as a management concept by the Iacocca Institute of Lehigh University.

In general, according to Akhtar et.al (2017) strategic agility is defined by the following four characteristics: speed, accuracy, cost efficiency and flexibility. The IT sector contributes 
to value generation among other industries, as it is a driver for continuous development. Alahyari et al. (2017) consider that the goal of strategic agility in the IT sector is to maximize the delivered value to the end customer. The authors differentiate between three types of value: Internal, customer and financial value. An overview over the previously mentioned characteristics of strategic agility match directly with the IT sector as well. The business environment is linked to IT. Jajja et.al (2018) claim that the supply chain of any company is enhanced and improved due to the IT business touch. The IT sector represents the nucleus of the business environment. In any business, there have to be at least the following actors: the customer, the company and the supplier. Thus, IT enables the supply chain in a fast, accurate, flexible and cost-efficient manner. Bratianu and Bolisani (2015) also consider that value creation is significant in having a strategic approach.

Serrador and Pinto (2015) consider that agile methods involve less planning and an increased level of flexibility. In a dynamic business environment, the IT sector embraces strategic agility as it brings real-time solutions to the challenges faced by the market's volatility and economic climate. From a cost perspective, the IT sector can be seen as a driver for sourcing savings opportunities and leverage on achieving company budget goals. Lowry and Wilson (2016) argue about the high return on investment companies make in the IT sector and about the fact that these effects are mirrored on how fast the companies will adapt to the changes of the business environment.

\section{Literature review}

\section{Strategic agility}

Strategic agility is an ability of the company to contributing to an increased overall performance and boost its market position, leveraging over the industry's competition. Battistella et al. (2017) say that the most successful companies use specific capabilities to be more proactive and focused into reaching strategic agility. The strong competition puts additional pressure on companies to become more agile and continuously think ahead in identifying new business opportunities. In the view of Fartash et. al (2017) agility represents a process of foreseeing new challenges and adapting them to the needs of the industry's user. According to the authors this process must be in alignment with the company's mission and vision, influencing the company's direction in a positive manner. Kale et. al (2018) view strategic agility as a response of the company in the battle for a better positioning on the market. It has an impact on the company's performance as it must be applied locally, nationally and internationally for increased business echo. To be agile, a company must follow up both its internal environment and be up to date with the external one, always focused to adjust fast the faced changes.

Kale et.al (2018) see strategic agility as a connector between absorptive capacity and firm performance. The authors define absorptive capacity as the ability to find out new opportunities and act for this from a commercial perspective. Strategic agility combined with absorptive capacity work together for improving the performance of a company. The three concepts build together a three-dimensional model as described in the below figure: 


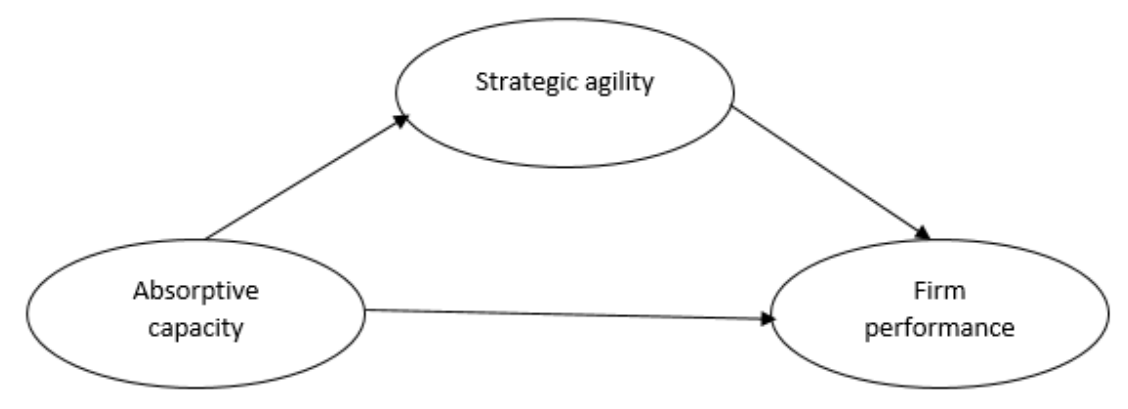

PICBE $\mid 136$

Fig.1 Strategic agility: Three-dimensional model

Source: Author's own representation

To better understand the three-dimensional model, we will take a more careful look to what each of the concepts stand for. To begin with, Zahra and George (2012) describe absorptive capacity as a dynamic way to enhance the company's knowledge to keep its competitive advantage on the market. Kale et.al (2018) argue that absorptive capacity is embedded in the routines of a company as part of the operations and processes involved. The focus on absorptive capacity has been addressed by Cohen and Levinthal (2000) who conclude in their study that absorptive capacity is integrated in the decision's calculus for resource distribution for innovation initiatives. Mayeh et. al (2016) argue that a way of integration of absorptive capacity in the decision making is via technology.

Strategic agility is according to Doz and Kosonen (2010) is the ability of a company to orientate in a strategic direction by reacting to the changes of the business environment and adapting in a flexible and fast manner. Strategic agility is therefore focused on the long-term perspective of how the company operates as part of the business landscape. The authors consider that strategic agility is enabled through strategic sensitivity, leadership unity and resource fluidity. Kumkale (2016) claims strategic agility is a crucial tool in fighting the fierce competition. To reach it, the author lists a series of enabling factors among them technology as well. The role played by technology in the achievement of strategic agility is vital. Technology helps in the identification of internal and external more specific in how the company is positioned in relationship with the business environment, where it matches the competitor's offering, what is lacks and nevertheless where is can make a new strategic move. According to Kale et.al (2018) the effects of strategic agility are rather visible in production and IT companies. Bratianu (2015) believes that using strategy is the equivalent to having a secure competitive advantage on the market, contributing to new business opportunities.

To complete the three-dimensional model, we must also address the firm performance concept. Kale et.al (2018) consider that the model is put into practice through acquisition, assimilation, transformation and exploitation.

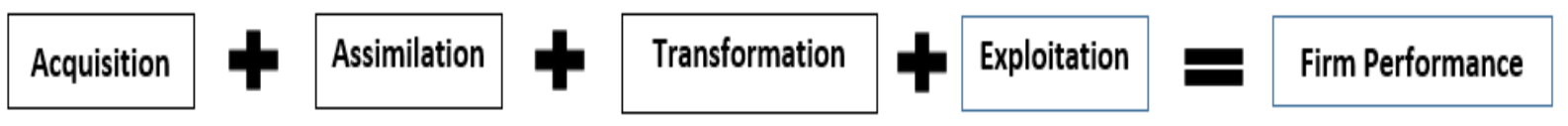

Fig 2. Firm performance pillars

Source: Author's own representation

DOI: 10.2478/picbe-2019-0013, pp. 134-148, ISSN 2558-9652| Proceedings of the $13^{\text {th }}$ International Conference on Business Excellence 2019 
These four characteristics are integrated in the firm's operations, influencing the performance of the company. Acquisition takes place when a company finds out external feedback, while assimilation is focused on embedding external information in the internal system. Transformation is at the border between external and internal, overseeing combining the internal and external received knowledge to deliver best results. Exploitation stands for further focus on potential company development as part of its continuous growth.

PICBE | 137

\section{Strategic agility in IT}

According to Akhtar et.al (2017) in IT strategic agility has three layers: operational, partnering, and customers. Operational agility stands for fast response on the market, partnering is charge with capturing the partner's market knowledge and using those into solving market issues. The customers' layer refers to the adaptability manner of strategic agility to adjust to the needs and wants of the market. Listening to the voice of the customer is definitely a successful recipe to leading a company into the right direction. Customer integration is fundamental in the adaptive process of any company as this layer is a bridge between the view of the customers and the view of the company. IT agility is the result of a combination between these layers orientated to improved results of the company.

$\mathrm{Xu}$ and Koivumaki (2018) see the IT sector as an example for strategic agility. The authors strongly believe that in IT one must think ahead the competition and act accordingly. To be more specific within the IT industry contributes with value added characteristics to product and services in a shorter cycle. The entire supply chain is digitalized, and the traditional production process becomes more efficient. Potdar and Routroy (2017) consider that the use of strategic agility in IT has contributed to the development of agile manufacturing. Technology plays a critical role together with the management pillar because it represents the foundation to a more efficient way of doing business. Jajja et.al (2018) argue that the supply chain of a company is directly connected to the internal and external turbulence surrounding the industry of the company. Kale et.al (2018) also believe that in order to reach strategic agility a company must follow both internal and external environmental changes.

Tan et.al (2017) consider that in IT companies' strategic agility is sourced through the alignment three operational stages: planning, production and distribution, also known as sales stage.

In an IT company a correct planning is vital in delivering the demanded and expected results to the final customer. In order to plan, an IT company must collect information from various stakeholders to fairly allocate resources and tasks' scheduling. The production stage is the most comprehensive one because it encapsulates a more sensitive alignment received from various units or departments in building it. All the incoming data becomes interdependent once released and it must coordinate and deliver.

The distribution stage takes place through data consolidation from the network and live update alignment to adjust rapidly if any issue arises. The instant support offered in the eventuality of a problem points out the previously mentioned characteristics of strategic agility in IT: flexibility, speed, accuracy and cost efficiency. Akhtar et.al (2017) support the Tan et.al (2017) view on strategic agility in the case of IT. Lowry and Wilson (2016) add that IT companies use strategic agility as a tool to spread information fast and in an effective manner to the points where it is mostly required.

DOI: $10.2478 /$ picbe-2019-0013, pp. 134-148, ISSN 2558-9652| Proceedings of the $13^{\text {th }}$ International Conference on Business Excellence 2019 


\section{Methodology}

The aim of the paper is to find out and define what strategic agility is and how it is reached within the IT section. Under the umbrella of the literature review the study aims to highlight the implications of strategic agility over the performance of IT companies. To ensure traceability we will define the following objectives for the paper: (1) define strategic agility for IT companies; (2) identify how strategic agility contributes to IT companies' performance; (3) connect the literature review with author's own contribution case analysis.

The paper uses a sample population gathered by the author via a Google Docs survey in December 2018. The sample is addressing stakeholders of top IT companies operating in Romania. The sample includes respondents working in the Romanian IT sector from various areas of the business: technical, support, operations, management.

In line with prior studies on strategic agility in IT, we have built the survey using a mixture of validated survey for the paper's topic. Most of the sections of the survey have been addressed by the respondents using a Likert scale. We have asked the respondents to select one option out of the following significance level: 1- Strongly Disagree, 2-Disagree, 3Undecided, 4- Agree, 5- Strongly agree.

In the development of the survey, the author has divided the survey structure as follows:

a. Sample including questions addressing topics as gender, age, studies, professional experience, job seniority

b. Strategic agility measurement questions adapted from Tallon and Pinsonneault (2011)

c. Absorptive capacity questions adapted from Flatten et. al (2011) covering acquisition, assimilation, transformation and exploitation pillars

d. IT and strategic agility questions adapted from Queiroz et. al (2018)

e. $\quad$ Performance question adapted from Queiroz et. al (2018)

The outcome of the survey resulted in 55 responses and a response rate of 68 per cent, all of them being valid

Further on, with the help of IBM SPSS Statistics Viewer we have conducted various sample analysis as Pearson's correlation, mean and standard deviation computation, together with a One Sample t Test analysis.

\section{Results and discussions}

To begin with, we have built the below sample characteristics table. It acts as synopsis of the sample analyzed to support us in having an overview of the respondents.

\begin{tabular}{lrr}
\multicolumn{3}{c}{ Table 1 Sample Characteristics $(\mathrm{N}=55)$} \\
\hline Gender & Frequency & Percent \\
Female & & \\
Male & 18 & $32.73 \%$ \\
\hline Age & 37 & $67.27 \%$ \\
$18-24$ & & \\
$25-34$ & 7 & $12.73 \%$ \\
& 23 & $41.82 \%$
\end{tabular}

DOI: 10.2478/picbe-2019-0013, pp. 134-148, ISSN 2558-9652| Proceedings of the $13^{\text {th }}$ International Conference on Business Excellence 2019 


\begin{tabular}{lrr}
$35-44$ & 17 & $30.91 \%$ \\
$45-54$ & 7 & $12.73 \%$ \\
$54-65$ & 1 & $1.82 \%$ \\
\hline Current Job Experience & & \\
1-3 Years & 19 & $34.55 \%$ \\
3-5 Years & 17 & $30.91 \%$ \\
5-10 Years & 11 & $20.00 \%$ \\
10-15 Years & 6 & $10.91 \%$ \\
Above 15 Years & 2 & $3.64 \%$ \\
\hline Seniority level & & \\
Entry & 9 & $16.36 \%$ \\
Medium & 22 & $40.00 \%$ \\
Senior & 11 & $20.00 \%$ \\
Managerial/ Leadership & 12 & $21.82 \%$ \\
Executive & 1 & $1.82 \%$ \\
\hline Studies & & \\
High-school & 1 & $1.82 \%$ \\
Bachelor's degree & 28 & $50.91 \%$ \\
Master's degree & 21 & $38.18 \%$ \\
PhD & 5 & $9.09 \%$ \\
\hline
\end{tabular}

Source: Author's own computation

For a better understanding of our sample we have performed a Pearson's correlation. As per Paunescu et. al (2018) we have used Pearson's correlation to check the level of dependence among our studied variables: performance, acquisition, assimilation, transformation, exploitation, strategic agility. According to Zhou et al. Pearson's correlation is one of the most popular measure of relationship within the literature review.

Table2 Pearson's correlation

\begin{tabular}{|c|c|c|c|c|c|c|c|}
\hline & & $\begin{array}{c}\text { Performanc } \\
\mathrm{e}\end{array}$ & $\begin{array}{l}\text { Acquisiti } \\
\text { on }\end{array}$ & $\begin{array}{l}\text { Assimilati } \\
\text { on }\end{array}$ & $\begin{array}{l}\text { Transformat } \\
\text { ion }\end{array}$ & $\begin{array}{l}\text { Exploitati } \\
\text { on }\end{array}$ & $\begin{array}{l}\text { Strate } \\
\text { gic } \\
\text { agility }\end{array}$ \\
\hline \multirow{4}{*}{$\begin{array}{l}\text { Performanc } \\
\mathrm{e}\end{array}$} & Pearson & 1 & 0.263 & 0.121 & 0.196 & $.357^{* *}$ & 0.151 \\
\hline & $\begin{array}{l}\text { Correlati } \\
\text { on }\end{array}$ & & & & & & \\
\hline & $\begin{array}{l}\text { Sig. (2- } \\
\text { tailed) }\end{array}$ & & 0.053 & 0.378 & 0.152 & 0.007 & 0.272 \\
\hline & $\mathrm{N}$ & 55 & 55 & 55 & 55 & 55 & 55 \\
\hline \multirow{3}{*}{ Acquisition } & $\begin{array}{l}\text { Pearson } \\
\text { Correlati } \\
\text { on }\end{array}$ & 0.263 & 1 & $.483^{* *}$ & $.346^{* *}$ & $.339^{*}$ & 0.115 \\
\hline & $\begin{array}{l}\text { Sig. (2- } \\
\text { tailed) }\end{array}$ & 0.053 & & 0.000 & 0.010 & 0.011 & 0.405 \\
\hline & $\mathrm{N}$ & 55 & 55 & 55 & 55 & 55 & 55 \\
\hline \multirow{2}{*}{ Assimilation } & $\begin{array}{l}\text { Pearson } \\
\text { Correlati } \\
\text { on }\end{array}$ & 0.121 & $.483^{* *}$ & 1 & $.549^{* *}$ & $.413^{* *}$ & 0.132 \\
\hline & $\begin{array}{l}\text { Sig. (2- } \\
\text { tailed) }\end{array}$ & 0.378 & 0.000 & & 0.000 & 0.002 & 0.335 \\
\hline
\end{tabular}

DOI: 10.2478/picbe-2019-0013, pp. 134-148, ISSN 2558-9652| Proceedings of the $13^{\text {th }}$ International Conference on Business Excellence 2019 


\begin{tabular}{|c|c|c|c|c|c|c|c|}
\hline & $\mathrm{N}$ & 55 & 55 & 55 & 55 & 55 & 55 \\
\hline \multirow{3}{*}{$\begin{array}{l}\text { Transformat } \\
\text { ion }\end{array}$} & $\begin{array}{l}\text { Pearson } \\
\text { Correlati } \\
\text { on }\end{array}$ & 0.196 & $.346^{* *}$ & $.549^{* *}$ & 1 & 0.199 & -0.059 \\
\hline & $\begin{array}{l}\text { Sig. (2- } \\
\text { tailed) }\end{array}$ & 0.152 & 0.010 & 0.000 & & 0.144 & 0.668 \\
\hline & $\mathrm{N}$ & 55 & 55 & 55 & 55 & 55 & 55 \\
\hline \multirow{3}{*}{ Exploitation } & $\begin{array}{l}\text { Pearson } \\
\text { Correlati } \\
\text { on }\end{array}$ & $.357^{* *}$ & $.339^{*}$ & $.413^{* *}$ & 0.199 & 1 & $.267^{*}$ \\
\hline & $\begin{array}{l}\text { Sig. }(2- \\
\text { tailed) }\end{array}$ & 0.007 & 0.011 & 0.002 & 0.144 & & 0.049 \\
\hline & $\mathrm{N}$ & 55 & 55 & 55 & 55 & 55 & 55 \\
\hline \multirow{3}{*}{$\begin{array}{l}\text { Strategic } \\
\text { agility }\end{array}$} & $\begin{array}{l}\text { Pearson } \\
\text { Correlati } \\
\text { on }\end{array}$ & 0.151 & 0.115 & 0.132 & -0.059 & $267^{*}$ & 1 \\
\hline & $\begin{array}{l}\text { Sig. (2- } \\
\text { tailed) }\end{array}$ & 0.272 & 0.405 & 0.335 & 0.668 & 0.049 & \\
\hline & $\mathrm{N}$ & 55 & 55 & 55 & 55 & 55 & 55 \\
\hline
\end{tabular}

Source: Author's own computation

For each of the variables the output the table there are 2 indicators: Pearson's correlation and Sig. (2-tailed). The first one indicates the actual coefficient correlation and it points out the strength of the linear relationship between the tested variables. The second indicator is the significance value. For our analysis we will compare it with the author's chosen level of significance, namely 0.05 . If the sample significance value is greater than 0.05 then it means that my correlation is not statistically significant. It occurred by chance. On the other hand, if our sample significance values is lower than 0.05 then there is enough evidence to suggest that the correlation we have obtained does exist in the population.

Looking at our sample's output for Pearson's correlation the table's notes indicate where the correlation is significant. Thus, we can state that there is positive correlation between most of the variables as: performance and exploitation, acquisition and assimilation, assimilation and transformation, transformation and acquisition, exploitation and assimilation. These mean that as one variable increases in value, the second one will increase as well. In some of the correlation cases, the sample significance value is greater than 0.05 so the correlation is not statistically significant.

Out of the below output there are three correlation relationship which are both positive and their corresponding significance values are lower than 0.05 . Acquisition and assimilation have a high value in Pearson's correlation coefficient, close to 1 . So, do assimilation and exploitation together with transformation and assimilation. This means that an increase in one variable is significantly related to an increase in the second variable.

Further on we have used descriptive statistics and correlations for our variables. The mean of each of the below listed variables. Looking at the obtained result we can say that for performance it will be 0.818 larger than the mean or 0.818 smaller than the mean of 4.13. The standard deviation column indicates how far each value deviates, how much it is DOI: 10.2478/picbe-2019-0013, pp. 134-148, ISSN 2558-9652| Proceedings of the $13^{\text {th }}$ International Conference on Business 
different from the mean. Out of the below values we notice that acquisition and exploitation have the lowest values in standard deviate, so we would have more consistent results. Acquisition and exploitation also have the highest score for mean so the respondents placed an average higher score for than for the rest of the variables.

Table 3 Mean, standard deviation and Pearson's correlations

PICBE | 141

Mean, standard deviation and Pearson's correlations

\begin{tabular}{|c|c|c|c|c|c|c|c|c|c|}
\hline & Mean & $\begin{array}{c}\text { Std. } \\
\text { Deviation }\end{array}$ & $\mathbf{N}$ & Performance & Acquisition & Assimilation & Transformation & Exploitation & $\begin{array}{c}\text { Strategic } \\
\text { agility }\end{array}$ \\
\hline Performance & 4.13 & 0.818 & 55 & 1 & & & & & \\
\hline Acquisition & 4.47 & 0.663 & 55 & 0.263 & 1 & & & & \\
\hline Assimilation & 4.18 & 0.884 & 55 & 0.121 & $.483^{* *}$ & 1 & & & \\
\hline Exploitation & 4.40 & 0.710 & 55 & $.357^{* *}$ & $.339^{*}$ & $.413^{* *}$ & 0.199 & 1 & \\
\hline $\begin{array}{c}\text { Strategic } \\
\text { agility }\end{array}$ & 4.42 & 0.762 & 55 & 0.151 & 0.115 & 0.132 & -0.059 & $.267^{*}$ & 1 \\
\hline
\end{tabular}

Source: Author's own computation

In order to validate how our sample is in relation with the literature review, we have applied via SPSS a One Sample t Test. As a reference we will use the obtained value of Tallon and Pinsonneault (2011) analysis for strategic agility. The value resulted for their study will be used as a benchmark value for our One Sample t Test analysis.

For the question "Respond to changes in aggregate consumer demand. (e.g. embed digital fingerprint unlock for a smartphone)" the mean value of the Tallon and Pinsonneault (2011) equals to 4.73. This value has been introduced in SPSS as a test value for our sample. Starting from the below shown output of the analysis we have compared the t value obtained of -3.0333 with the value corresponding to the Student t Test distribution table using the 0.05 significance level. Under the degrees of freedom of 54, where 54 is the difference between $\mathrm{N}$ and 1 we have the value of 1.645 .

Table 4 Sample Statistics

One-Sample Statistics

\begin{tabular}{|c|c|c|c|c|}
\hline & $\mathrm{N}$ & Mean & Deviation & Mean \\
\hline $\begin{array}{l}\text { Strategic } \\
\text { agility }\end{array}$ & 55 & 4.42 & 0.762 & 0.103 \\
\hline
\end{tabular}

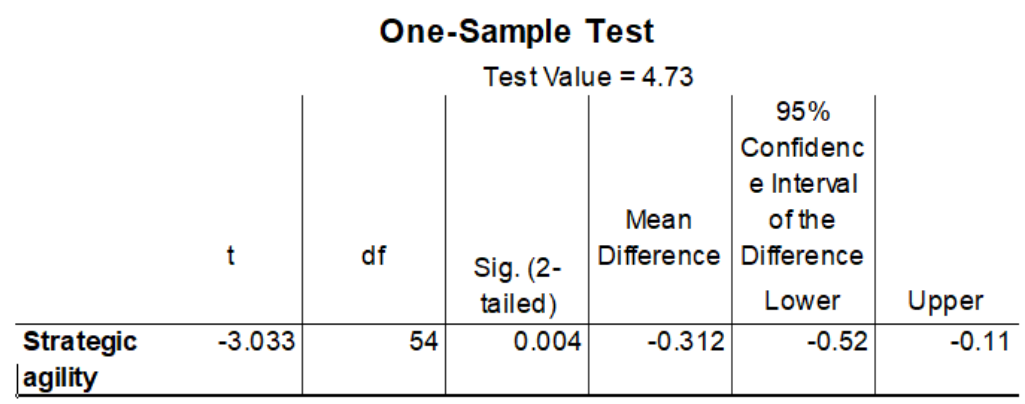

Source: Author's own computation 
The critical value of 1.645 is larger than our $t$ value of -3.033 therefore we can state that the means are not different. Under the null hypothesis where there is no difference, we would expect $t$ to be 0 . Also, the confidence interval does not include 0 and the $p$ value equals to 0.004 is smaller than 0.05 . Having all these checked, we can state that we can reject the null hypothesis. Therefore, there is a significant difference between sample mean and the population mean. The confidence interval $(-0.52 ;-0.11)$ points out that in 95 per cent of the cases the interval will capture the true population mean and in 5 per cent of them it will not.

Further on, we will analyze the input provided in the survey by our respondents. As mentioned in the methodology section, the survey was divided as follows: sample understanding, strategic agility measurement, absorptive capacity, IT strategic agility and performance. Analyzing the below graphs for strategic agility, we can say that two of the main features of strategic agility, namely change and react to market changes are strongly supported by our sample. As outlined below in figure 3 and figure 4, almost half of the respondents agree and strongly agree that change and reaction to external business factors are high contributor indicators to strategic agility. These outcomes are confirming Doz and Kosonen (2010) view on strategic agility.

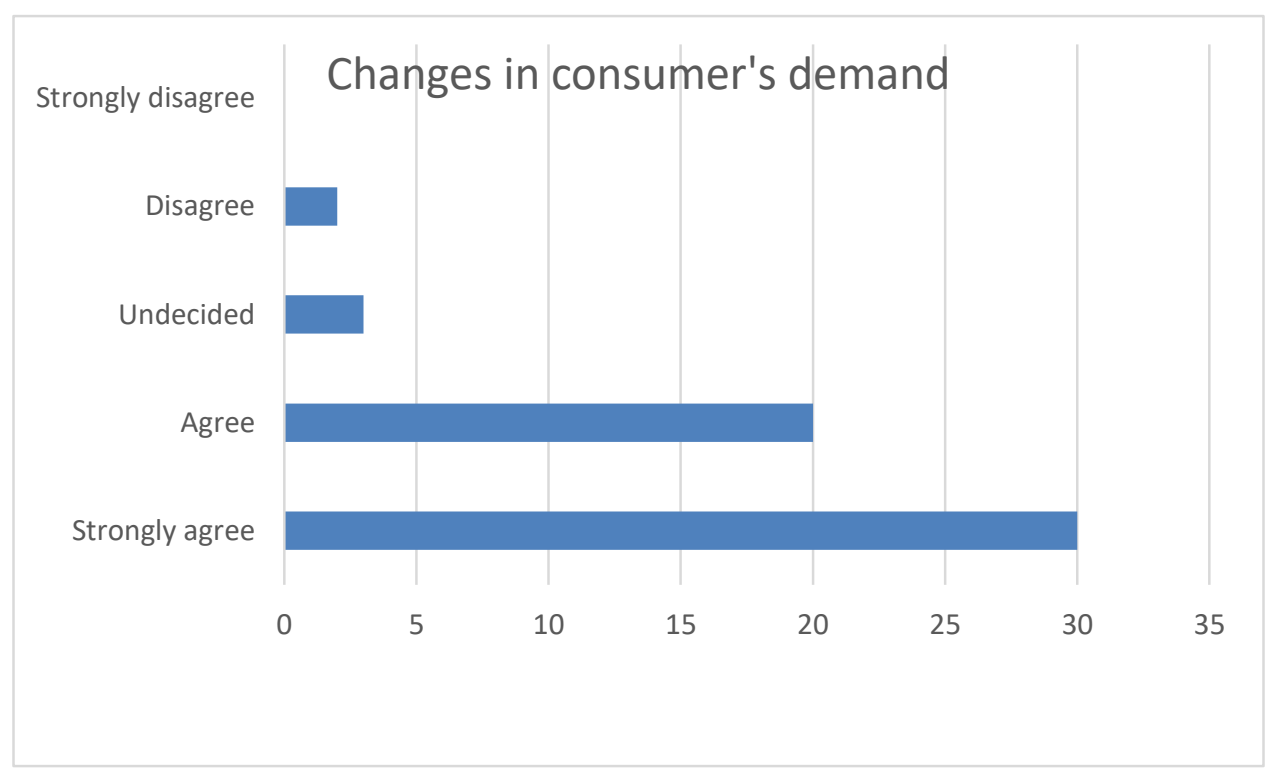

Fig. 3 Changes in consumer's demand

Source: Author's own representation

To obtain these results the respondents had to select from a Likert scale from 1 to 5 with gradually level of significance, to be more specific $1=$ strongly disagree, $2=$ agree and so on up till $5=$ strongly agree. The above graph, figure 3 has been obtained by asking the respondents to rank from 1 to 5 the question How easily and quickly can your firm respond to changes in aggregate consumer demand. (e.g. embed digital fingerprint unlock for a smartphone). 55 per cent of the sample strongly agrees that the IT company that they are working for is easily and quickly responding to changes of the business environment. Another 36 pe cent of the sample has selected "agree" for this question. Previously we have commented the results of this question in the statistics analysis using as benchmark the outcome of Tallon and Pinsonneault (2011). The author's analysis contributes to the findings

DOI: 10.2478/picbe-2019-0013, pp. 134-148, ISSN 2558-9652| Proceedings of the $13^{\text {th }}$ International Conference on Business 
of the literature review. As explained by Kale et.al (2018) a fast response to the business changes indicate the presence of strategic agility. Therefore, we can state that change is a confirmed factor part of strategic agility in the IT sector.

Part of the survey questions, the respondents have been asked to rank again with the help of Likert scale the following question" React to new product or service launches by competitors." We have tested the same question as Tallon and Pinsonneault (2011). Looking at the below outcome, we can state that 55 per cent of the respondents strongly believe that their company is responding to the moves performed by their competition. To this indicator we must sum up another 33 per cent who have selected that they agree their company is reacting to the competitors' move. We can state that almost half of the respondents confirm the fact that their company is influenced and is following the competition direction, reacting to this with new market moves.

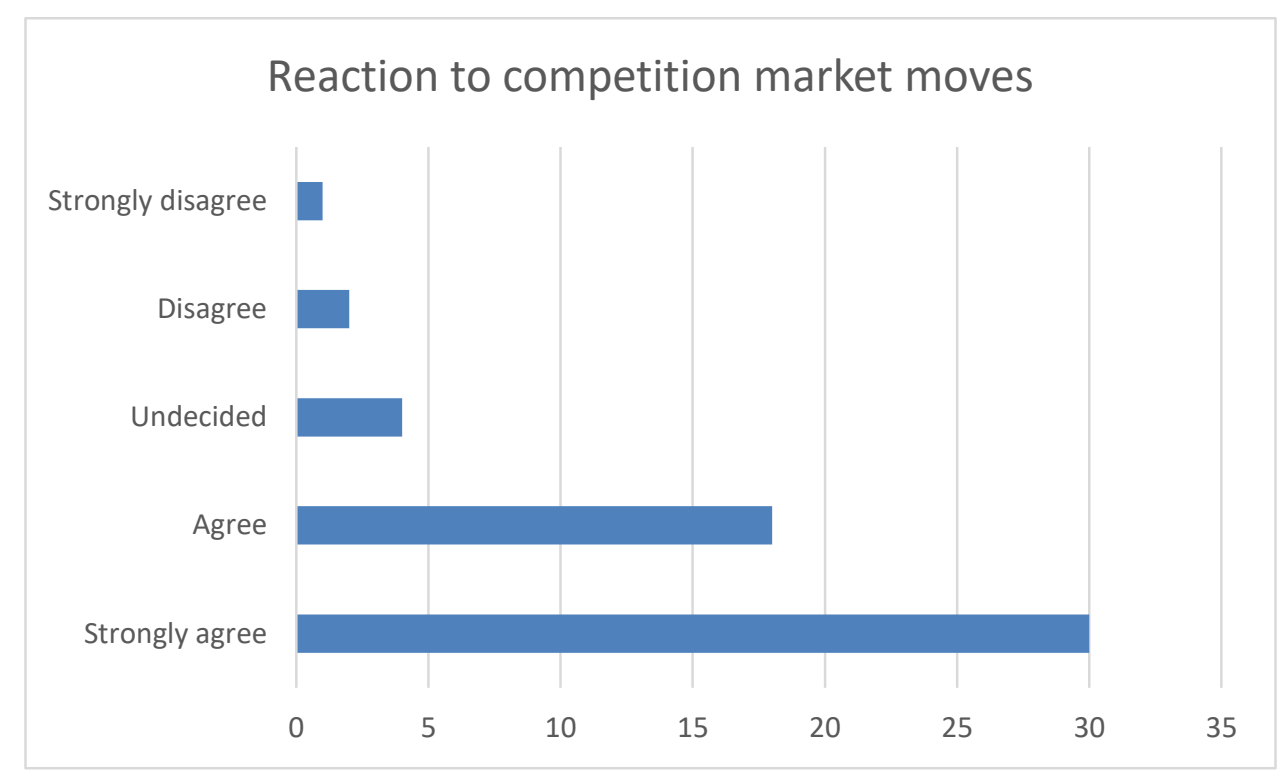

Fig. 4 Reaction to competition market moves

Source: Author's own representation

The high indicators which resulted from our sample analysis confirm the definition of strategic agility provided by Doz and Kosonen (2010). Furthermore, we notice that the respondents have been consistent in answering the two questions targeting the features of strategic agility. The authors believe that change and reaction to business environmental moves represent an ability of the company encapsulated under the concept of strategic agility.

For testing absorptive capacity, the sample answered questions on acquisition, assimilation, transformation and exploitation. Out of the four pillars of Kale et.al (2018) model, a significant part of 30 percent of the respondents believe that acquisition is one of the most important ones. For each of the four pillar models the respondents had to answer different questions.

The below graph representation for acquisition is the output result for the question" The search for relevant information concerning our industry is every-day business in our

DOI: $10.2478 /$ picbe-2019-0013, pp. 134-148, ISSN 2558-9652| Proceedings of the $13^{\text {th }}$ International Conference on Business 
company." Therefore, we can state that a significant part of the sample considers their employer is continuously seeking external industry understanding. Transformation and exploitation have also been in the top preference of the sample. The fact that for each of the four model parts, none of the respondents had chosen "strongly disagree" we can state that each of the pillar is important to our sample as they do not reject the contribution of any of them.

The question regarding acquisition has been "The search for relevant information concerning our industry is every-day business in our company". Out of these four performance pillars, we can state that acquisition of the most influential pillar, as 30 per cent of the sample has selected "strongly agree". Zahra and George (2002) consider that acquisition is less significant than transformation and exploitation. In our findings, transformation is the performance pillar which confirms both Zahra and George (2002) and Kale et.al (2018) studies.

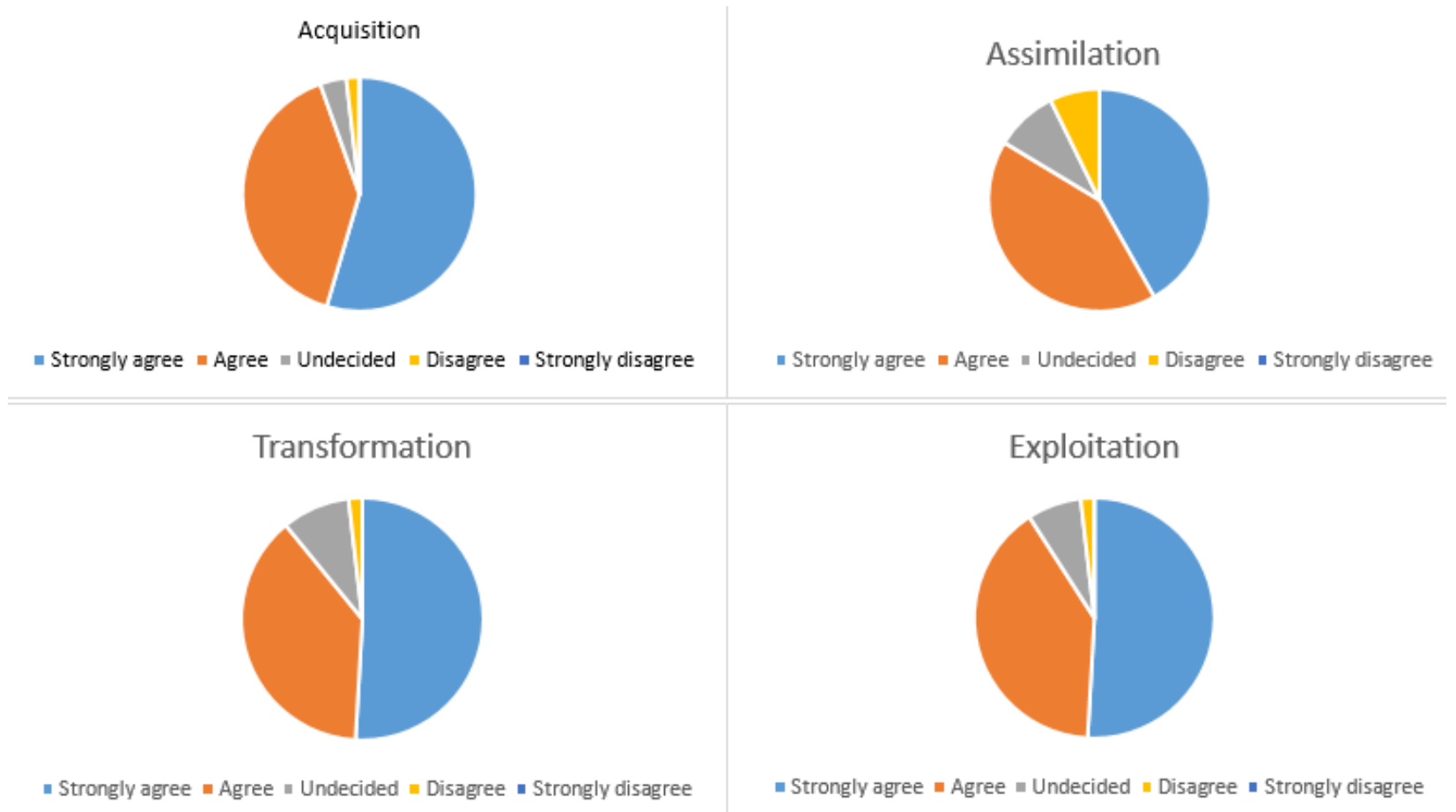

Fig. 5 Kale's performance pillars

Source: Author's own representation

Transformation has been outlined in the survey with the help of the following question "The employees can structure and to use collected knowledge. (e.g. you can contribute with process improvement ideas)". The results are aligned with the opinion of Zahra and George (2002). The authors believe that transformation is an ability for development and reshape of business activities, combining old and new information. The fact that 51 per cent of the sample has chosen "strongly agree", complemented by another 38 per cent who has chosen "agree" to this question points out the importance of transformation as a performance pillar. 
Exploitation has been tested by asking the respondents to rank from 1 to 5 the question "Our company regularly reconsiders technologies and adapts them accordant to new knowledge." On the same pattern adapted from Flatten et. al (2011), we have tested the sample for assimilation as well with "Our company regularly reconsiders technologies and adapts them accordant to new knowledge. Exploitation has been confirmed by 51 per cent of the sample who strongly agree on its contribution while for assimilation 42 per cent have selected "strongly agree". Aligned with Kale et.al (2018) and Zahra and George (2002) studies, exploitation proved to be more influential than assimilation. This points out that in order to reach performance a company should focus constantly on innovation and enhancing existing capabilities.

Another point approached in the survey has been strategic agility in IT. The respondents were asked to answer if their company develops IT applications internally. Over 50 per cent of the sample is confirming the assumptions of Queiroz et. al (2018) on the implication of IT in strategic agility. Also 36 per cent of the sample has stated they agree that their company develops in-house applications. The positive results confirm Queiroz et. al (2018) opinion that in the IT sector strategic agility adds value to the business and the development of IT applications leads to an improved agility of a business. Analyzing figure 4 together with figure 6 we can state that Xu and Koivumaki (2018) statements on IT strategic agility is confirmed. One must react to competition moves in IT, our results indicating that over 80 per cent of the sample is also concerned with in-house applications development.

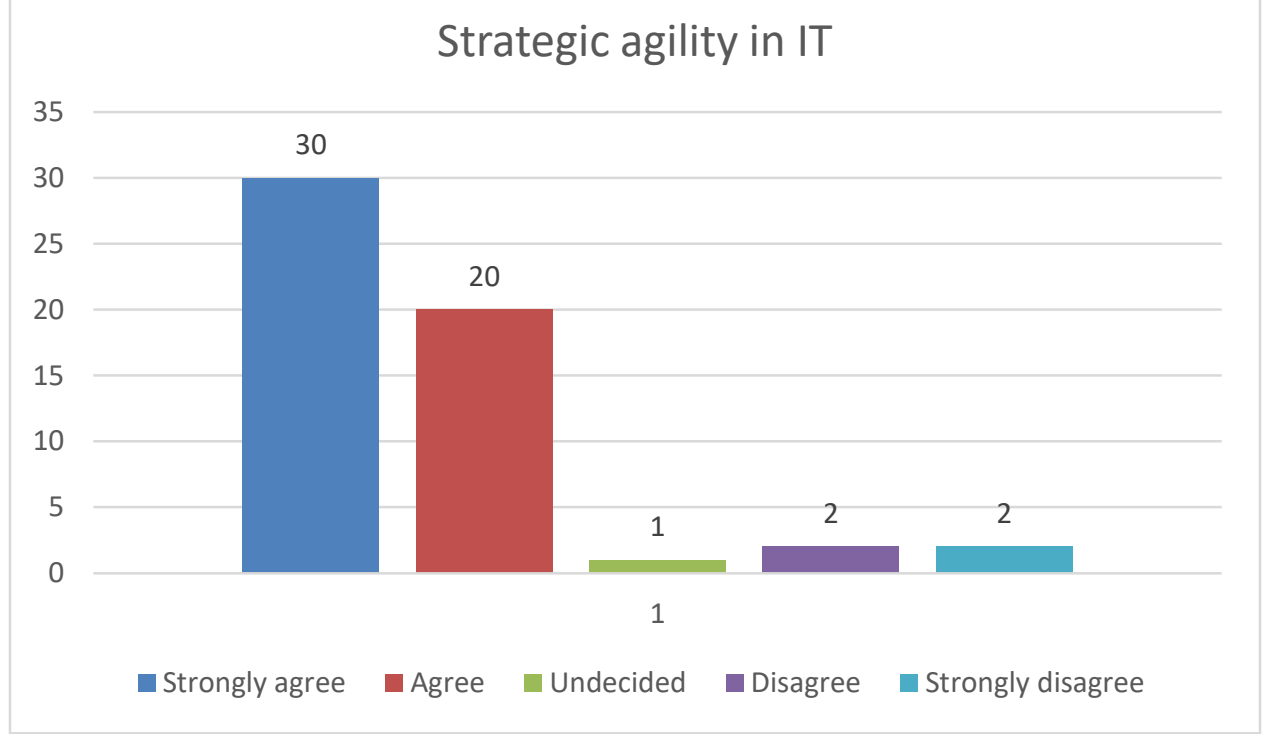

Fig. 6 Strategic agility in IT

Source: Author's own representation

\section{Conclusion}

The paper has touched each of the three defined objectives. We have managed to deep dive the literature review using various sources to define strategic agility for the IT sector, testing these definitions with developing a survey and engaging a sample to test it. Next, we have applied a statistics analysis to check how strategic agility contributes to the performance of an IT company. The results of the Pearson's correlations mean, and standard deviation 
computations point out the positive relationships as follows: exploitation and assimilation, exploitation and performance, assimilation and acquisition, assimilation and transformation, transformation and acquisition. Our results show that the presence of strategic agility confirmed by over 70 per cent of the sample on various survey questions, indicating a significant contribution of strategic agility to the performance of a company. Change and competition reaction together with Kale's performance pillar on acquisition, assimilation, exploitation and transformation confirm the three-dimensional model of strategic agility, absorptive capacity and firm performance. Further on, we have managed to link the literature review with a real case study, built with the help of an online survey addressed to stakeholders working in IT companies. Doing so, we were able to test different theoretical concepts and identify new relationships and correlations among them.

The limitations of the paper regard various limitations. The sample cannot be generalized, as the obtained output results are significant for the author' sample. The analysis of the literature review can be used as a guiding point for better understanding the concept of strategic agility and firm performance for IT companies. Another limitation is related to the volume of the respondents. Further on, considering the number of respondents, their input is validated only for the specific analyzed case. It cannot be extended as a general rule, it is significant for the current paper. The paper brings a contribution to the literature review together with new insights for IT companies in terms of strategic agility implications and factors influencing the firm's performance. It can be used in the planning and development of business strategy for quarterly or yearly review meetings. It can also be used for start-up companies who want to have an overview on scientific and business practicalities for their business plan.

All in all, the paper presents evidence about the factors influencing strategic agility for IT companies. A three-dimensional model of strategic agility, absorptive capacity and firm performance is tested through a survey and a deeper SPSS analysis. Using the literature review, we have provided extending knowledge on the topic, identifying and proving new correlation relationships between acquisition and assimilation, assimilation and exploitation together with transformation and assimilation. Out of Kale's four pillars transformation has proved to be the most significant one as a major contributor to firm performance, confirming the studies of the literature review as well.

\section{References}

Akhtar, P., Khan, Z., Tarba, S., \& Jayawickrama, U. (2018). The Internet of Things, dynamic data and information processing capabilities, and operational agility. Technological Forecasting and Social Change, 136, 307-316.

Alahyari, H., Svensson, R. B., \& Gorschek, T. (2017). A study of value in agile software development organizations. Journal of Systems and Software, 125, 271-288.Chae, H.C., Koh, C.E. and Park, K.O., 2018. Information technology capability and firm performance: Role of industry. Information \& Management, 55(5), pp.525-546.

Bratianu, C., \&amp; Bolisani, E. (2015, September). Knowledge strategy: An integrated approach for managing uncertainty. In European Conference on Knowledge Management Academic Conferences International Limited, 18(1), 169-177.

Bratianu, C. (2015). Developing strategic thinking in business education. Management Dynamics in the Knowledge Economy, 3(3), 409.

DOI: 10.2478/picbe-2019-0013, pp. 134-148, ISSN 2558-9652| Proceedings of the $13^{\text {th }}$ International Conference on Business 
Cohen, W. M., \& Levinthal, D. A. (2000). Absorptive capacity: A new perspective on learning and innovation, in 'Strategic Learning in a Knowledge economy', 1 (1)

Doz, Y. L., \& Kosonen, M. (2010). Embedding strategic agility: A leadership agenda for accelerating business model renewal. Long range planning, 43(2-3), 370-382.

Flatten, T. C., Engelen, A., Zahra, S. A., \& Brettel, M. (2011). A measure of absorptive capacity: Scale development and validation. European Management Journal, 29(2), 98-116.

Kale, E., Aknar, A., \& Başar, Ö. (2018). Absorptive capacity and firm performance: The mediating role of strategic agility. International Journal of Hospitality Management., 76, 77-96

Koufteros, X., Vonderembse, M., \& Jayaram, J. (2005). Internal and external integration for product development: the contingency effects of uncertainty, equivocality, and platform strategy. Decision Sciences, 36(1), 97-133.

KUMKALE, İ. (2016). Organization's Tool For Creating Competitive Advantage: Strategic Agility. Balkan and Near Eastern Journal of Social Sciences, 2(3), 118-124.

Lowry, P. B., \& Wilson, D. (2016). Creating agile organizations through IT: The influence of internal IT service perceptions on IT service quality and IT agility. The Journal of Strategic Information Systems, 25(3), 211-226.

Jajja, M. S. S., Chatha, K. A., \& Farooq, S. (2018). Impact of supply chain risk on agility performance: Mediating role of supply chain integration. International Journal of Production Economics, 205, 118-138.

Mayeh, M., Ramayah, T., \& Mishra, A. (2016). The role of absorptive capacity, communication and trust in ERP adoption. Journal of Systems and Software, 119, 58-69.

Păunescu, C., Popescu, M., \& Duennweber, M. (2018). Factors Determining Desirability of Entrepreneurship in Romania. Sustainability, 10(11), 3893.

Paunescu, C., 2009. Managing process performance and quality for sustainability in the service organizations. Amfiteatru Economic Journal, 11(26), pp.323-329.

Potdar, P. K., \& Routroy, S. (2017). Analysis of Agile Manufacturing Enablers: A Case Study., $21(2), 117-135$

Serrador, P., \& Pinto, J. K. (2015). Does Agile work? A quantitative analysis of agile project success. International Journal of Project Management, 33(5), 1040-1051.

Shin, H., Lee, J. N., Kim, D., \& Rhim, H. (2015). Strategic agility of Korean small and medium enterprises and its influence on operational and firm performance. International Journal of Production Economics, 168(1), 181-196.

Stachowiak, A., Hadaś, Ł., Cyplik, P., \& Fertsch, M. (2013). Decision model for sustainable and agile resources management. IFAC Proceedings Volumes, 46(9), 1140-1145.

Tallon, P. P., \& Pinsonneault, A. (2011). Competing perspectives on the link between strategic information technology alignment and organizational agility: insights from a mediation model. Mis Quarterly, 35 (2), 463-486.

Tan, F. T. C., Tan, B., Wang, W., \& Sedera, D. (2017). IT-enabled operational agility: An interdependencies perspective. Information \& Management, 54(3), 292-303.

Queiroz, M., Tallon, P. P., Sharma, R., \& Coltman, T. (2018). The role of IT application orchestration capability in improving agility and performance. The Journal of Strategic Information Systems, 27(1), 4-21.

Xu, Y., \& Koivumäki, T. (2018). Digital business model effectuation: An agile approach. Computers in Human Behavior., 89, 102-116

DOI: 10.2478/picbe-2019-0013, pp. 134-148, ISSN 2558-9652| Proceedings of the $13^{\text {th }}$ International Conference on Business 
Zahra, S. A., \& George, G. (2002). Absorptive capacity: A review, reconceptualization, and extension. Academy of management review, 27(2), 185-203.

Zhou, H., Deng, Z., Xia, Y., \& Fu, M. (2016). A new sampling method in particle filter based on Pearson correlation coefficient. Neurocom, 216(1), 208-215

PICBE | 148

DOI: 10.2478/picbe-2019-0013, pp. 134-148, ISSN 2558-9652| Proceedings of the $13^{\text {th }}$ International Conference on Business Excellence 2019 